\title{
On Ethnography, Politics, and Critique
}

Blair Rutherford Carleton University

On Rutherford, Blair. Farm Labor Struggles in Zimbabwe: The Ground of Politics. Bloomington: Indiana University Press, 2017, 294 pages.

Like many anthropologists, I have tried to make my research contribute to some sort of "social change," particularly as it is often looking at intermeshed racialized, classed, gendered power and social relations that produce uneven configurations of exploitation, immiseration, and accumulation in different sub-Saharan African countries. In my academic writing, this ambition can lead me to focus on how a critical politics can emerge, or has emerged (Li 2019). In so doing, I recognize that both the cultural politics of my positioning informs the reception of my research with different audiences and publics (for example, Hamdy 20I7) and as my research occurs in jurisdictions other than those where I live and far from my home in Ottawa, as Tania Li $(2019,43)$, put it, "[e]ffective politics ... requires intellectual and organisational resources that go far beyond those a visiting anthropologist could possibly supply."

I am thus especially grateful to Anthropologica for being able to use David Moore's thoughtful and thorough review of my last ethnography, Farm Labor Struggles in Zimbabwe (Rutherford 2017), as a way to receive brief commentaries about the review and the book from two sharp anthropologists who work on agrarian dynamics and struggles in southern Africa, namely, Lincoln Addison and Andrew Hartnack. Aside from it being flattering to see the Ground of Politics ${ }^{1}$ getting so much thoughtful and critical discussion, I also welcome the opportunity to briefly discuss wider disciplinary perspectives on politics and critique.

I Moore's suggestion that this subtitle of my book, which emerged through a conversation I had with Zimbabwean scholar Amanda Hammar, should have been the title is spot-on, as that was my original intent as well. But I was persuaded by the publisher that putting "Zimbabwe" in the title would have a greater reach. 
Moore is a Canadian professor of Development Studies at the University of Johannesburg and a well-known scholar of politics in Zimbabwe (for example, Moore I99I, 200I, 2004, 20I8) as well as a frequent and perspicacious commentator on Zimbabwean politics in regional and international media. He is thus a very relevant interlocutor for my book, which examines poritikisi ("electoral politics" in ChiShona) and a long, bitter farm labour struggle that took place on a small plantation outside of Harare from late 1998 to early 2000. In retrospect, this period was transformational in terms of national politics and economy in this southern African country, as a greater push for "democracy" sparked both the emergence of a new and very popular political party in 1999 and a massive and highly politicized (on a localized, national and international scale) land distribution program starting in 2000 targeting white-owned farms by the ruling party then under the leadership of Robert Mugabe.

Moore generously recommends my book to those commentators on Zimbabwean politics from other disciplines (like political science, his own), suggesting that its attentiveness to the grounding of national politics in specific struggles like this farm labour dispute sheds new light on political dynamics in the country. As readers of Anthropologica know, such alertness to "scale-making projects" (Tsing 2000) is a common feature of more ethnographies, showing how the social and power relations and their contestations that anthropologists learn about through participant observation can be entangled in wider-scale conditions and arrangements in a variety of ways (an exemplary example and, as Hartnack observes, an influence on my writing, is Donald Moore's 2005 ethnography, Suffering for Territory). David Moore does suggest that I could have considered systemizing my analysis a bit more, examining, for example, if there is any overlap between shifts in political party allegiance and accumulation or survival practices, as such a taxonomy may be more helpful to, what I am assuming, other (comparative?) studies than my own heuristic tools of 'social projects' and 'belonging.'

Such a (mild) criticism is apropos, for despite my aim that (some of) my analytical arguments be suitable for analyses of agrarian and other dynamics and disputes elsewhere, I crafted them in a way to speak to what I saw as the critical political possibilities that conditioned this particular farm labour struggle in light of the larger political situation facing men and women, permanent and seasonal farm workers in Zimbabwe, at least in regards to this turn-of-the century conjuncture and potentially to the very different situation there in the current period. 
The commentary from Addison and Hartnack intersect here. They each have written recent and erudite ethnographies examining wider and localized politics affecting Zimbabwean farm workers in, respectively, northern South Africa (Addison 2019) and post-2000 Zimbabwe (Hartnack 2016). Addison rightly notes caution as the theme in my discussion of those promoting social justice and human rights in this book. I was drawn into this labour struggle by its social justice causes and articulated commitments, its relative effectiveness in bringing in a range of political actors and civic organizations, all of which initially led me to naively entertain thoughts that my research was part of an activist anthropology aligned to this organized struggle to change conditions (Hale 2008). Yet, over time I learned more of the complex terrain and then divergent social and political projects, leading to a greater care in assessing and deploying such energizing terms (see, for example, Stuesse 2015).

All three note the very different situation in present-day Zimbabwe. Addison points out a very different cultural politics of farm labour there today, in its particular arrangements across diverse agrarian settings and its articulation with state-inflected institutional configurations (for example, Bulawayo 24 News 2020), let alone in imaginaries at diverse scales. In turn, Hartnack observes the importance of having more nuanced views of politics, as my book argues, even though political oppression and economic instability are even more widespread in the country, even with a "new old man" (Scarnecchia 20I7) in charge of the ruling party after an internal coup. There are others, often younger Zimbabwean scholars, forging new languages and approaches to the ongoing politics and activism shaping, forging, and denying new possibilities for social change (in addition to Hartnack's work, see also, for example, Chitukutuku 20I7, Mudiwa 20I7). Through ethnographic attentiveness, they seek to "make sense of the

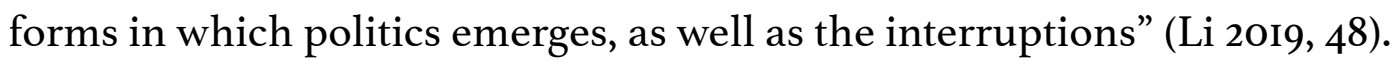

Even though my argument suggests that practices of poritikisi entail danger, violence, and other forms of embodied perils for many in places like Zimbabwe, critically attending to the movements and struggles for some forms of freedom and social change, such as workers' rights- examining the multiscalar forms of belonging, affects, and social projects mobilized in what can be viewed as the grounds of politics-is the least that politically-engaged anthropologists can strive to do.

\author{
Blair Rutherford, \\ Carleton University, \\ blair.rutherford@carleton.ca
}




\section{References}

Addison, Lincoln. 20I9. Chiefs of the plantation: Authority and contestation on the South Africa-Zimbabwe border. Montreal and Kingston: McGill-Queen's University Press.

Bulawayo 24 News. 2020. “Uproar over 'slavery' on Zimbabwe farms.” Bulawayo 24 News, 2I September. https://bulawayo24.com/index-id-news-sc-national-byo-II8209.html (accessed 3I October 2020).

Chitukutuku, Edmore. 20I7. "Rebuilding the liberation war base: materiality and landscapes of violence in Northern Zimbabwe." Journal of Eastern African Studies II(I): I33-I5O.

Hale, Charles (ed.). 2008. Engaging contradictions: Theory, politics, and methods of activist scholarship. Berkeley and Los Angeles: University of California Press.

Hamdy, Sherine. 20I7. "How publics shape ethnographers: Translating across divided audiences." In D. Fassin (ed.), If truth be told: The politics of public ethnography, 287-309. Durham: Duke University Press.

Hartnack, Andrew. 20I6. Ordered estates: Welfare, power and maternalism on Zimbabwe's (once white) Highveld. Harare: Weaver Press.

Li, Tania. 20I9. "Politics, interrupted." Anthropological Theory I9(I): 29-53. https://doi. org/IO.II77/I4634996I8785330

Moore, David. 199I. “The ideological formation of the Zimbabwean ruling class.” Journal of Southern African Studies I7(3): 472-495. https://doi.org/IO.IO80/03057079108708288

Moore, David. 200I. "Neoliberal globalisation and the triple crisis of 'modernisation' in Africa: Zimbabwe, the Democratic Republic of the Congo and South Africa." Third World Quarterly 22(5): 909-929. https://doi.org/I0.I080/0I436590I20099713

Moore, David. 2004. "Marxism and Marxist Intellectuals in Schizophrenic Zimbabwe: How Many Rights for Zimbabwe’s Left? A Comment." Historical Materialism I2(4): $405-425$.

Moore, David. 20I8. “A very Zimbabwean coup: November 13-24, 2017." Transformation: Critical Perspectives on Southern Africa 97: I-29. https://doi.org/IO.II63/I569206043505257

Moore, Donald. 2005. Suffering for territory: Race, place, and power in Zimbabwe. Durham: Duke University Press.

Mudiwa, Rudo. 20I7. “Feeling precarious.” Transition I23: 79-88. DOI:IO.2979/transition. I23.I.08 
Rutherford, Blair. 2017. Farm labor struggles in Zimbabwe: The ground of politics. Bloomington: Indiana University Press.

Scarnecchia, Timothy. 2017. "The new Old Man in Zimbabwe." Africa is a Country, https://africasacountry.com/2017/II/the-new-old-man-in-zimbabwe.

Stuesse, Angela. 2015. "Anthropology for whom?' Challenges and prospects of activist scholarship." In Public Anthropology in a Borderless World, edited by Sam Beck and Carl Maida, 22I-246. New York: Berghahn.

Tsing, Anna. 2000. “The global situation." Cultural Anthropology I5(3): 327-360. https:// doi.org/IO.I525/can.2000.15.3.327 